\section{The effects of easy and difficult business relationship evaluations on purchase intentions}

\author{
Juan José Camou Viacava ${ }^{1}$ \\ Paulo de Paula Baptista ${ }^{1}$ \\ ${ }^{1}$ Pontifícia Universidade Católica do Paraná, Business School, PPAD, Curitiba, \\ Brazil.
}

\begin{abstract}
Purpose - This research aims to investigate the different impacts of easy (fluency) and difficult (disfluency) business relationship evaluations on future purchase intentions. In addition, it seeks to investigate the mediating role of confidence in these evaluations and present a new form of fluency manipulation performed directly by satisfaction evaluations.

Design/methodology/approach - This research includes a first experiment with a 3 (fluency: easy vs difficult vs control) x 2 (hypothetical scenario of satisfaction vs dissatisfaction) factorial design, using 180 undergraduate students, and a second single factor experiment (fluency: easy vs difficult vs control) with 326 consumers evaluating their financial services provider. Both used a between-subject design with the individuals being randomly distributed between the scenarios.
\end{abstract}

Findings - Dissatisfied consumers who perceived ease in evaluating commercial relationships have increased confidence in these evaluations, negatively influencing their purchase intentions. Meanwhile, satisfied consumers are generally overconfident, being equally affected by perceived difficulty or ease due to a direct bias from the evaluation, which increases purchase intentions.

Originality/value - The results demonstrate that fluency (perceived ease or difficulty) depends on the valence of the evaluations, directly affecting (positive valence) or indirectly affecting (negative valence) subsequent decisions. We also present a new, faster, and more practical way to manipulate fluency. Furthermore, we raise some ethical questions as these effects result in biased decisions.

Keywords - fluency, bias, valence, confidence, purchase intention.
Received on:

$11 / 03 / 2019$

Approved on:

06/01/2020

Responsible Editor:

Prof. Dr. Sebastián Molinillo

\section{Evaluation process:}

Double Blind Review

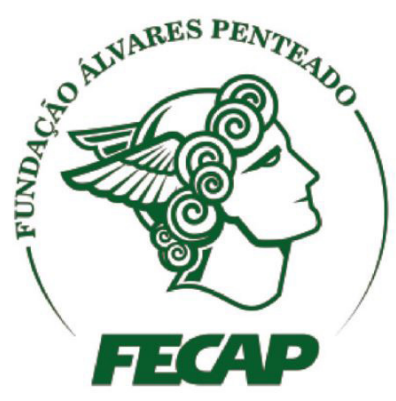

Revista Brasileira de Gestáo de Negócios 


\section{Introduction}

Individuals usually seek to simplify decisions using "shortcuts" or heuristics that minimize cognitive efforts and avoid stress and strain in their decisions (Kahneman, 2011). However, these "shortcuts" usually produce some biases that influence attitudes and decisions. In relationship marketing, one of these biases has its origin in satisfaction evaluations, leading to a pattern of future expectations associated with higher repurchase rates (Oliver, 2010). Similarly, the development of loyalty can also be seen as a cognitive bias that directs attitudes and behaviors (Bloemer, Ruyter, \& Peeters, 1998). The explanation for these biased behaviors is based on the positive memories experienced (Lazarus, 1991), but it is also necessary to highlight the influence of fluency (Schwarz, 2004) on the creation and reinforcement of these biases, intensifying the impact of intuitions and opinions (Aydin, 2016; Simons \& Nelson, 2006, 2007).

At one end of the fluency continuum, individuals perceive ease in cognitive processing, creating comfort and pleasure (Labroo \& Pocheptsova, 2016; Nunes, Ordani, \& Valsevia, 2015) that would lead to biases such as: intensifying the effects of what is being interpreted (Claypool, Mackie, \& Garcia-Marques, 2015; Landwehr, Golla, \& Reber, 2017); evaluating and judging something more quickly (Schwarz, 2004); a greater perception of veracity, familiarity, learning, intelligence, and value (Alter \& Openhaimer, 2006, 2008, 2009; Kornell, Rhodes, Castel, \& Tauber, 2011; Miele \& Molden, 2010; Openhaimer, 2004; Yang, Huang, \& Shanks, 2018). In addition, as evaluations get more intuitive, faster, and more confident (Kahneman, 2011), subsequent judgments and decisions show more biases (Aydin, 2016; Simons \& Nelson, 2006, 2007). Perceived difficulty can be observed at the other end of the fluency continuum (Sanchez \& Jaeger, 2015), linked to cognitive discomfort and thoughts about risk. However, if individuals could be stimulated to deliberate or to use their self-control (Kahneman, 2011), they would not develop overconfidence and would avoid using simple opinions and prior and/or erroneous beliefs - or even xenophobic thoughts - that could bias their decisions (Alter, 2013; Hernandez \& Preston, 2013; Ryffel \& Wirth, 2018).

Therefore, if consumers experienced easy and difficult assessments and judgments, would it be possible to lessen the impact of positive or even negative business experiences just by making the consumer doubt the evaluation? Is confidence in evaluations and subsequent decisions differently affected by positive and negative commercial experiences? In order to answer these questions, this study aims to verify the impact of fluency on commercial relationship evaluations and on subsequent future purchase intentions. In addition, the study also presents a new fluency manipulation (based on Oppenheimer, 2004), not requiring previous tasks to affect later evaluations, but directly using easy or difficult satisfaction evaluations, and therefore enabling it to be applied in practice.

\section{Literature Review}

Despite the need and importance, in several situations consumers do not rationally and structurally judge the attributes, benefits, and costs of each purchase. Instead, they use a series of simplified rules (i.e. heuristics) without making in-depth comparisons and evaluations (Baron, 2008). These heuristics generate systematic errors, called biases, arising from factors such as lack of self-control and fluency (Kahneman, 2011). The latter is the subject of this study.

\section{I Effects of fluency on evaluations and judgments}

Fluency can be understood as a continuum between ease (fluency) and difficulty (commonly called disfluency) of processing some type of information. The intensity of fluency can originate from the individual's own characteristics or from the situation being evaluated and it can be classified as perceptual or conceptual fluency (Schwarz, 2004). Perceptual fluency results from physicalvisual characteristics, such as changes in brightness, contrast, or even in the print quality of texts. Conceptual fluency results from ease of processing a given stimulus, such as easy to pronounce names or even rhyming phrases. As an example, studies show that easy to pronounce stock names or symbols, therefore having greater fluency, create greater expectations of profitability for investors (Alter \& Oppenheimer, 2006).

Stimuli perceived as easy have a greater tendency to be hedonically processed (Duke, Fiacconi, \& Kohler, 2014). Thus, in general, people prefer music (rhythms and their lyrics), texts, and the like with simpler content, as they get cognitive comfort from the pleasure of being able to understand it without much effort (Bayliss, Constable, Tipper, \& Kritikos, 2013; Maier \& Dost, 
2018; Nunes, et al., 2015). Ease of processing is linked to perceived pleasure, reducing uncertainties and eliciting more positive responses when evaluating products (Labroo $\&$ Pocheptsova, 2016). This cognitive comfort can even increase the acceptance of an idea, topic, or even a product (Labroo, Dhar, \& Schwarz, 2008). However, pleasure is not felt when processing all stimuli types, only positive ones (Albrecht \& Carbon, 2014). That is, there is no preference or pleasure in processing negative stimuli. In this sense, extreme ease of processing intensifies the effects of previously processed information, whether positive or negative, stimulating biases that influence future decisions (Claypool et al., 2015; Landwehr et al., 2017).

Although individuals have a preference for easier stimuli, difficulty (disfluency) generally helps them process information more carefully, acting as a warning to prevent more intuitive forms of reasoning (Alter, 2013; Alter, Oppenheimer, Epley, \& Eyre, 2007). Difficulty in cognitive processing is able to interrupt confirmatory biases, beliefs, previous expectations, and prejudices (Hernandez $\&$ Preston, 2013), leading to better event coding, better memory retrieval later (Diemand-Yauman, Oppenheimer, \& Vaughan, 2011; Oppenheimer \& Alter, 2013), and better information processing. Thus, perceived difficulty provides superior results (Charness \& Dave, 2017) by enforcing greater deliberation in the decision-making process (Weissgerber \& Reinhard, 2017).

Heuristics and their biases are associated with System 1, where the process of seeking cognitive comfort leads to less and faster deliberation, producing overconfidence. On the other hand, in the case of System 2 , there is slow thinking, more deliberation, and greater attention (Kahneman, 2011). Likewise, individuals who have previously had easy cognitive processing experiences overestimate their knowledge about these experiences, generating greater confidence (Ryffel \& Wirth, 2018). Ease of processing can induce a greater perception of veracity (Silva, Garcia-Marques, \& Reber, 2017) and overconfidence, because individuals do not have to deal with inconsistencies or new interpretations in deliberations (Bajšanski, Žauhar, \& Valerjev, 2019). Similarly, studies testing the effects of technical versus common words (or even easy versus difficult to read typefaces) point out that perceived ease is related to a greater perception of information confidence, while difficulty leads to a greater risk perception (Park, Herr, \& Kim, 2016).

Therefore, easily formed intuitions and opinions not only lead to results with greater perceived reliability, but also to greater confidence in the evaluation or judgment itself. Overconfident individuals do not engage in new information processing and are directly biased by these intuitions. However, if they have faced difficulties in forming these intuitions, this would signal to them that less intuitive alternatives should be considered, or even chosen (Simons \& Nelson, 2006, 2007). As a result, individuals who easily formed prior choices of which product to buy would have greater confidence that these prior choices would be right, increasing subsequent purchase intentions (Aydin, 2016).

However, evidence indicates that this would not always happen because not only perceived ease or difficulty can affect confidence, but also mood states (Koch $\&$ Forgas, 2012) and the evaluated valence of memories (Kensinger \& Schacter, 2008).

\subsection{Effects of the valence of memories on evaluations and judgments}

Positive mood states lead to judgments that are perceived as "more true," causing the maintenance of confidence, while negative mood states lead to less confidence in information processing (Koch \& Forgas, 2012).

Confidence in what is being evaluated is negatively affected by negative recovered memories, involving more effort and need for control to avoid unwanted results (Caplan, Sommer, Madan, \& Fujiwara, 2019). Negative emotions induce a more concrete adaptive processing state, leading individuals to process information with greater attention and for longer periods (Matovic, Kock, \& Forgas, 2014). These effects relate to evidence that negative events are more accessible to memory, enhancing the recollection of details and central facts (Hostler, Wood, \& Armitage, 2018; Kensinger $\&$ Schacter, 2008) that are essential and intrinsic to the events (Bookbinder \& Brainerd, 2017; Kensinger, 2009) because they include more distinct memories (Brewin \& Langley, 2019).

Negative emotions stimulate the ability to recapitulate episodes not only due to greater attention to coding and memories retrieval, but also due to the greater reactivation of these emotions (Bowen, Kark, $\&$ Kensinger, 2017). Thus, negative aspects, facts, and emotions result in greater attention and prevention in general (Prato \& John, 1991), as well as a greater problem-solving focus (Orita \& Hattori, 2018).

In contrast, positive memories lead to more general and peripheral attention (Talarico, Berntsen, \& 
Rubin, 2009). These memories need more associations to be remembered (Madan, Scott, \& Kensinger, 2019) and they therefore have more inconsistencies (recall errors). The recovery of positive memories seems to be associated with greater confidence in their reports (Kensinger, 2009). Positive emotions lead individuals to focus on more abstract aspects, with less focus on and less attention paid to external information, seeking to maintain the pleasant feelings (Bless \& Fiedler, 2006). This greater confidence also relates to the way people have been treated (Lazarus, 1991). People treated in a welcoming way, who had positive experiences, would feel safer and more "loose," reducing their worries and their need to not make a fool of themselves (p. 421). These positive mood states lead to the relaxation of inhibitory control, resulting in a fundamental shift in attention (Rowe, Hirsh, \& Anderson, 2007).

In general, situations with negative affect lead to memories with greater precision and focus than positive affect (Kensinger, 2009), and similarly, positive memories lead to less details and accuracy compared to negative memories (Bohn \& Berntsen, 2007; Brewin \& Langley, 2018). With this lack of focus, in time individuals have a higher probability of remembering only the "essence" of the positive event - they would only "know" that something positive had happened, without any great precision or even forgetting details (Kensinger, 2009). Additionally, judgments focused on positive aspects are faster and more spontaneous than judgments focused on negative aspects (Herr \& Page, 2004). Positive evaluations are relatively more automatic, leading to lower quality and more biased decisions (Herr, Page, Pfeiffer, \& Davis, 2012). Also, Sorbeck and Clore (2005) indicate that positive aspects lead to a greater disconnection between confidence and the vividness of memories. That is, even if positive memories are not as distinct and vivid in certain situations, they still lead to greater confidence. Thus, while negative moods lead people to focus on details, positive moods make them deliberate more, based more on schematics or heuristics (Rowe et al., 2007).

\subsection{Fluency and the effects of the valence of memories on commercial relationship evaluations}

Among some of the "shortcuts" used for decision making, individuals commonly use prices (Luppe \& Angelo, 2010) and previous satisfaction evaluations - their own or from others - as anchors in buying decisions (Oliver, 2010). Such behavior is related to individuals' tendency to reuse previous methods that have obtained satisfactory results (Baron, 2008). Consumers' past purchase satisfaction (Oliver, 2010) or even information from others' satisfactory experiences (Agnihotri, Dingus, $\mathrm{Hu}, \&$ Krush, 2016) create positive expectations for the decision maker because they develops a belief that their needs can be fulfilled with similar performance in the future. This creates an expectation of satisfaction (Sirgy, 1984; Oliver, 2010) and the anticipation of positive emotions (Patrick, Chun, \& Macinnis, 2009). In this sense, satisfaction evaluations made before purchasing decisions serve as an anchor for substitution heuristics and thus, as opinions or intuitions, they will mostly be used, replacing complex questions that would bias subsequent decisions (Kahneman, 2011).

Satisfaction itself is an overall evaluation of expectations, benefits, value, and quality compared to the perceived costs of business relationships. It is an evaluation of the performance of these factors compared to expectations. Positive disconfirmation of expectations would lead the consumer to be satisfied and feel positive emotions and affect. Negative disconfirmation leads the consumer to be unsatisfied, feeling negative emotions and affect (Oliver, 2010). Commercial interactions with positive evaluations develop trust, commitment, and true loyalty (Grönroos, 2009; Larivière et al., 2016) - or even a bias that can influence attitudes and behaviors (Bloemer et al., 1998) - resulting in better financial results (Francisco-Mafezzolli \& Prado, 2013; Fornell, Morgeson, \& Hult, 2016).

As dissatisfied consumers have negative memories, emotions, and affections associated with their suppliers, they have more vivid and distinct memories (Brewin \& Langley, 2019). Thus, decisions regarding these suppliers would be more focused on central aspects (Kensinger, 2009), that is, with attention paid to essential facts and intrinsic details (Bookbinder \& Brainerd, 2017; Kensinger, 2009) for problem solving (Orita \& Hattori, 2018). Remembering their negative episodes, these consumers focus on their negative memories. As they perceive higher fluency (perceived ease) in their satisfaction evaluations, they develop greater confidence in their own evaluations (Simons \& Nelson; 2006, 2007; Aydin, 2016), intensifying the negative aspects (Claypool, et al., 2015; Landwehr, et al., 2017) of the commercial relationship, thus decreasing the purchase intentions for that supplier. However, even if they 
have less confidence because of perceived difficulty, this will only make them more vigilant and assume a general state of prevention, focusing on the problem (purchase decision) and beginning to doubt their intuitions (in that they should not buy from the supplier). Therefore, we propose that:

H1: Fluency (perceived ease) will increase a dissatisfied consumer's confidence in their relationship evaluations, subsequently reducing their purchase intentions.

Satisfied consumers have positive memories, emotions, and affections associated with their commercial products/services suppliers and, therefore, they make more abstract decisions, more focused on more general aspects (Talarico et al. 2009) and less so on external information (Bless \& Fiedler, 2006). In this case, they feel safer and more "relaxed," with fewer worries (Lazarus, 1991), less attention paid, and less self-control (Rowe et al. 2007). Satisfied consumers make more automatic judgments and thus more biased ones. Even if they cannot recall as many details, they have greater confidence in their evaluations (Kensinger, 2009; Sorbeck \& Clore, 2005) and are more influenced by heuristics (Rowe et al. 2007). Therefore, even in disfluency situations (perceived difficulty) satisfied consumers do not experience a significant drop in confidence in their ability to evaluate their satisfaction. Therefore, if they have remembered positive facts/memories before a purchase decision, their interpretations and evaluation results will still be intensified (Claypool et al. 2015; Landwehr et al. 2017), despite the difficulty perceived. Therefore, we propose that:

H2: Commercial relationship evaluations (fluency or disfluency) will directly bias satisfied consumers to increase their subsequent purchase intentions.

\section{Methodological Procedures}

We used an experimental methodology to test the hypotheses (Figure 1), manipulating the independent variables and thus increasing the probability of an effect occurring (Shadish, Cook, \& Campbell, 2002), measuring the manipulation (checking) and its effects on the dependent variables while at the same time controlling the other external variables (Malhotra, 2010). We used non-probabilistic sampling for convenience in both experiments. The first experiment used a sample of undergraduate students while the second one used a general sample of several bank customers contacted through social networks and via e-mail.
In both experiments, a new form of fluency manipulation was used based on Oppenheimer's (2004) manipulation, which manipulated fluency with texts using difficult words.

For the "easy" task (perceived ease), the individuals answered four overall satisfaction questions (Prado, 2004) before answering a purchase intention question. The four satisfaction questions to evaluate commercial relationships were: three questions adapted from Bettencourt (1997) and Fornell, Johnson, Anderson, Cha, \& Bryant (1994) (overall satisfaction, expectations distance, and global disconfirmation) and one affective evaluation question from Garbarino \& Jonhson (1999). For the "difficult" task (perceived difficulty), instead of directly asking these four questions, the concept of each item (taken from Prado, 2004) was written in a question format and these four conceptual questions were asked before the individuals indicated their purchase intention. As an example, the first question from Prado (2004), "How would you rate your satisfaction regarding your relationship with ALPHA, the provider of residential telephony, internet, and cable TV services?" was adapted in the "difficult" task scenario to "Overall, how would you evaluate your commercial relationship with ALPHA, the provider of residential telephony, internet, and cable TV services focusing on the services offered regarding the act or effect of satisfaction?" For the "control" group, the individuals indicated their purchase intentions and later completed the four-item scale from Prado (2004).

In both experiments, all groups (set of "easy" vs "difficult" commercial relationship evaluations before indicating the purchase intention, vs Control - without commercial relationship evaluations before indicating the purchase intention) answered the four standard satisfaction questions (Prado, 2004) at the end of the questionnaire to check manipulation (experiment 1) and unbiased evaluations of business relationships (experiment 2). Moreover, to verify that these manipulations not only resulted in greater difficulty, but were also convergent with the results of other studies, the results of the satisfaction evaluations were compared with Haddock (2002) and other authors. Haddock (2002) demonstrated that, in a task involving remembering one politician's positive aspects, individuals in easy tasks (remembering few facts) developed more favorable opinions about the politician than those in difficult tasks (remembering more facts). Likewise, in tasks involving remembering one politician's negative aspects, individuals in easy tasks (remembering few 
facts) developed less favorable opinions about the politician than those in difficult tasks (remembering more facts). Similar results were found when investigating personal use of bicycles (Aarts \& Dijksterhuis, 1999), aspects of childhood (Winkielman \& Schwarz, 2001), and satisfaction evaluations (Viacava, Mantovani, Korelo, \& Prado, 2015). Thus, we also expect unsatisfied consumers with perceived difficulty in commercial relationship evaluations to have higher satisfaction scores than those with evaluations they perceived as easy. Similarly, we expect satisfied consumers with perceived difficulty in commercial relationship evaluations to have lower satisfaction scores than those with evaluations they perceived as easy.

\section{I Experiment I}

Procedures: the experiment presented a 3 (fluency: "easy" vs "difficult" vs control) x 2 (positive scenario: "satisfaction" vs negative: "dissatisfaction") factorial design. A total of 189 undergraduate students started the test but only 180 completed the survey and were therefore considered as valid $\left(52.20 \%\right.$ men, $\mathrm{M}_{\text {age }}=22.14$ years, $\mathrm{SD}=4.36)$.

In a classroom at the university, the students randomly assigned to one of six conditions filled in a survey (Appendix A - first experiment questionnaires) about commercial relationships (cable TV, home telephone, and internet providers). The students were given one of two scenarios ("satisfaction" vs "dissatisfaction") consisting of fictional stories about a consumer named Eduardo. In the "positive" scenario, the customer had a threeyear relationship that resulted in positive expectancy disconfirmation (general and attendance service quality, deadlines fulfilled, perceived cordiality, etc.) and the development of positive overall satisfaction. In the "negative" scenario, "Eduardo" also had a three-year relationship but the same situations resulted in negative expectancy disconfirmation and the development of negative overall satisfaction ("dissatisfaction"). After reading the scenarios, they answered two other unrelated surveys ("fillers") averaging five minutes, so that the scenarios were not so evident and close to the evaluations phase ( $\mathrm{Su}, \mathrm{Li}$, Zheng, Hu, Fan, \& Luo, 2018).

Next, fluency ("easy" vs "difficult" vs "control") was manipulated by the complexity of the satisfaction evaluations. For the "easy" task (perceived ease), the individuals answered four overall satisfaction questions (Prado, 2004) before indicating their purchase intentions. For the "difficult" task (perceived difficulty) they answered four adapted questions made for each concept item (taken from Prado, 2004) before indicating their purchase intention. The control group only indicated their purchase intention and, later, manipulation of the scenarios was checked (Figure 2 - experiment 1 flow).

As a dependent variable, all answered the purchase intention question (regarding a cable TV offer made by the same company described in the scenario, based on 1 - certainly NOT to 10 - definitely YES). Then

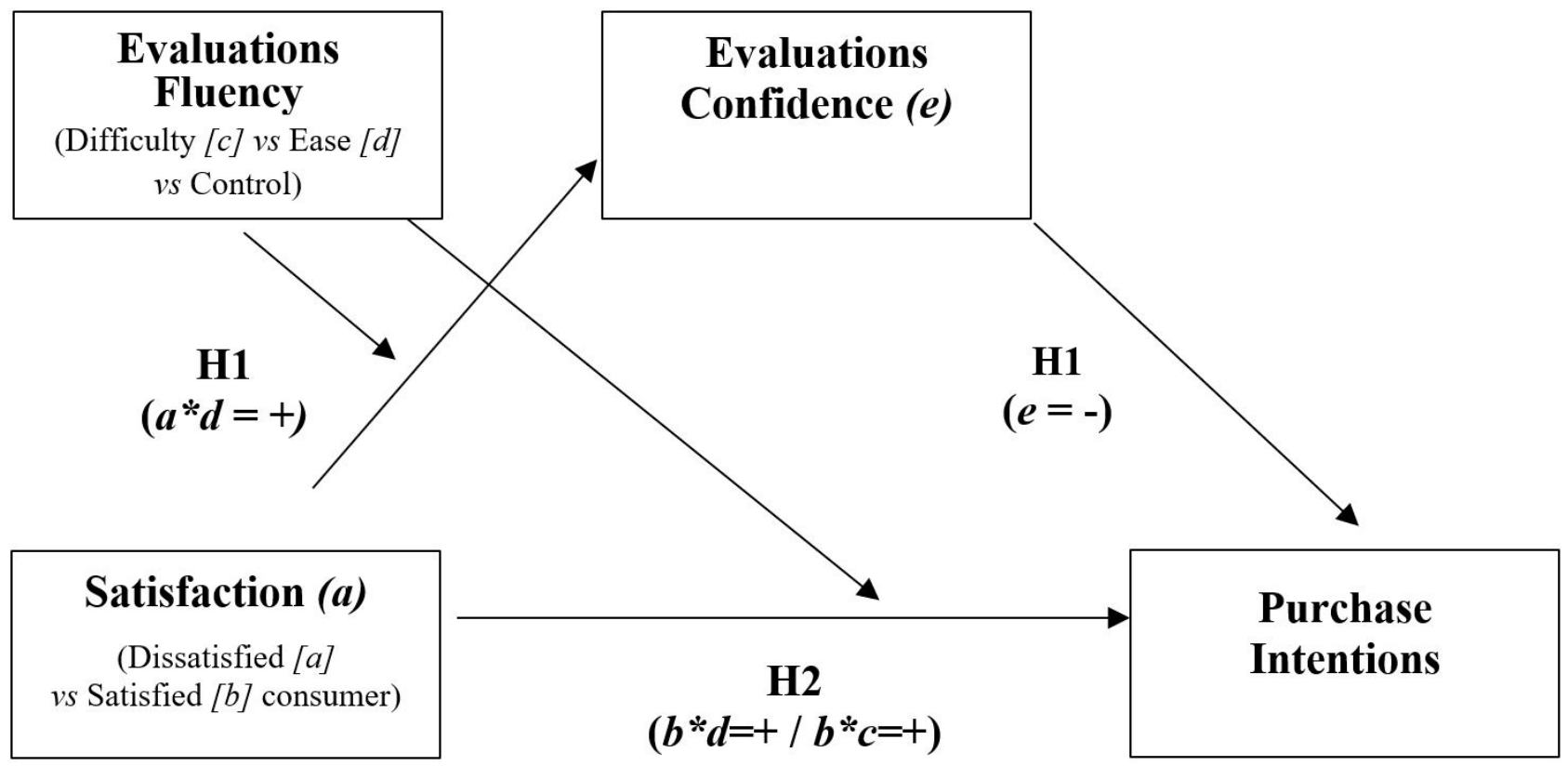

Figure 1. Conceptual Framework for the Hypotheses 


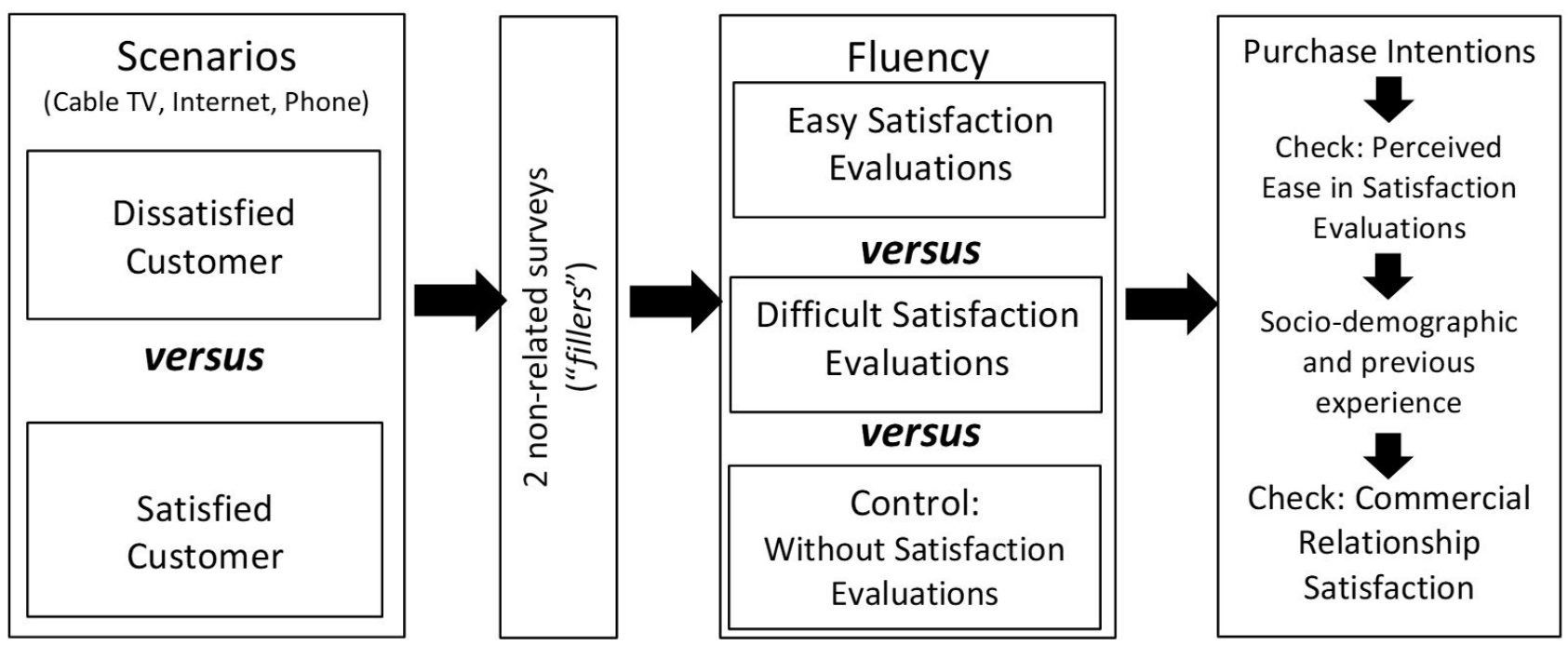

Figure 2. Experiment 1 Flow.

they answered the fluency manipulation check, which questioned the general perceived difficulty (Graf, Mayer, \& Landwehr, 2018) to evaluate satisfaction (1 - very difficult to 10 - very easy). The students also reported their actual satisfaction with their own internet, cable, and phone provider services and how much they paid for them, followed by socio-demographic questions (these variables reveal non-significant relationships with the results). Before ending the experiment, all answered a four-item overall satisfaction scale (Prado, 2004) as a scenario manipulation check.

Manipulation checks: he one-way anova test revealed that individuals in the "easy" group perceived that it was easier to answer the four satisfaction items $\left(F(2,177)=12.127, p<0.001, \eta_{\mathrm{p}}^{2}=0.121, \mathrm{M}_{\text {easy }}=\right.$ $6.43, \mathrm{SD}=1.99, \mathrm{M}_{\text {control }}=5.90, \mathrm{SD}=1.66, \mathrm{M}_{\text {difficult }}=$ $4.86, \mathrm{SD}=1.42 / p_{\text {easyXdifficult }}=0.005, p_{\text {easyXcontrol }}=0.196$, $\left.p_{\text {controlXdifficult }} 0.005\right)$. An independent $t$ test using the average of the four satisfaction items (Cronbach's alpha $=0.984)$ also reveals the expected results for the scenarios $\left(t(1,178)=16.745, p<0.001, \mathrm{M}_{\text {satisfaction }}=7.27, \mathrm{SD}=1.59\right.$, $\left.\mathrm{M}_{\text {dissatisfaction }}=3.19, \mathrm{SD}=1.67\right)$. The two-way anova test revealed a significant interaction between the independent variables (fluency: "easy" vs "difficult" / "dissatisfaction" vs "satisfaction" $\left(F(1,115)=12.015, p=0.001 \eta_{\mathrm{p}}^{2}=0.095\right)$ and the average satisfaction (four items, Cronbach's alpha $=0.970)$ questioned before purchase intentions, showing the same pattern as other related studies (Aarts \& Dijksterhuis, 1999; Haddock, 2002; Viacava et al., 2015; Winkielman \& Schwarz, 2001). Perceived difficulty reduced the average satisfaction of the positive scenario ("satisfaction": $\mathrm{M}_{\text {easy }}=7.55, \mathrm{SD}=1.43, \mathrm{M}_{\text {difficult }}=6.47$, $\mathrm{SD}=1.36 / p=0.009)$ it increased the average satisfaction of the negative scenario ("dissatisfaction": $\mathrm{M}_{\text {easy }}=2.88$, $\mathrm{SD}=1.46, \mathrm{M}_{\text {difficult }}=3.74, \mathrm{SD}=1.76 / p=0.027$ ).

Results: the two-way anova test revealed a significant interaction of the independent variables $(F(2,174)=10.142$, $\left.p<0.001, \eta_{\mathrm{p}}{ }^{2}=0.104\right)$ with purchase intention (PINT) (Figure 3), with a significant effect of the scenario $(F(1,174)$ $=160.964, p<0.001, \eta_{\mathrm{p}}^{2}=0.481, \mathrm{PINT}_{\text {satisfaction }}=7.21$, $\left.\mathrm{SD}=1.67, \mathrm{PINT}_{\text {dissatiffaction }}=3.82, \mathrm{SD}=2.06\right)$ and a nonsignificant effect of fluency $(F(2,174)=1.984, p=0.141$, $\eta_{\mathrm{p}}^{2}=0.022, \mathrm{PINT}_{\text {easy }}=5.34, \mathrm{SD}=2.95, \mathrm{PINT}_{\text {control }}=$ 5.57, $\mathrm{SD}=2.26, \mathrm{PINT}_{\text {difficult }}=5.75, \mathrm{SD}=2.23$ ).

Bonferroni post hoc tests in the positive scenario corroborated hypothesis 2 , showing that commercial relationship evaluations, whether perceived as easy or difficult, lead to higher purchase intentions compared to the control group ("satisfaction" PINT easy $_{\text {}}=7.71$, $\mathrm{SD}=1.48, \mathrm{PINT}_{\text {control }}=6.44, \mathrm{SD}=1.98, \mathrm{PINT}_{\text {difficult }}=$ $7.65, \mathrm{SD}=0.83 / p_{\text {easyXcontrol }}=0.011, p_{\text {easyXdifficult }}=1.000$, $\left.p_{\text {controlXdifficult }}=0.037\right)$.

The results from the Bonferroni post hoc tests in the negative scenario corroborated hypothesis 1 . Perceived ease leads to lower purchase intentions compared to the other groups ("dissatisfaction": PINT $_{\text {easy }}=2.91$, $\mathrm{SD}=1.92, \mathrm{PINT}_{\text {control }}=4.48, \mathrm{SD}=2.13, \mathrm{PINT}_{\text {difficult }}=$ $4.24, \mathrm{SD}=1.81 / p_{\text {easyXcontrol }}=0.002, p_{\text {easyXdifficult }}=0.010$, $\left.p_{\text {controlXdifficult }}=0.999\right)$.

Discussion: Although the two hypotheses were initially corroborated, some limitations arose. First, there was a small, though significant difference in perceived 


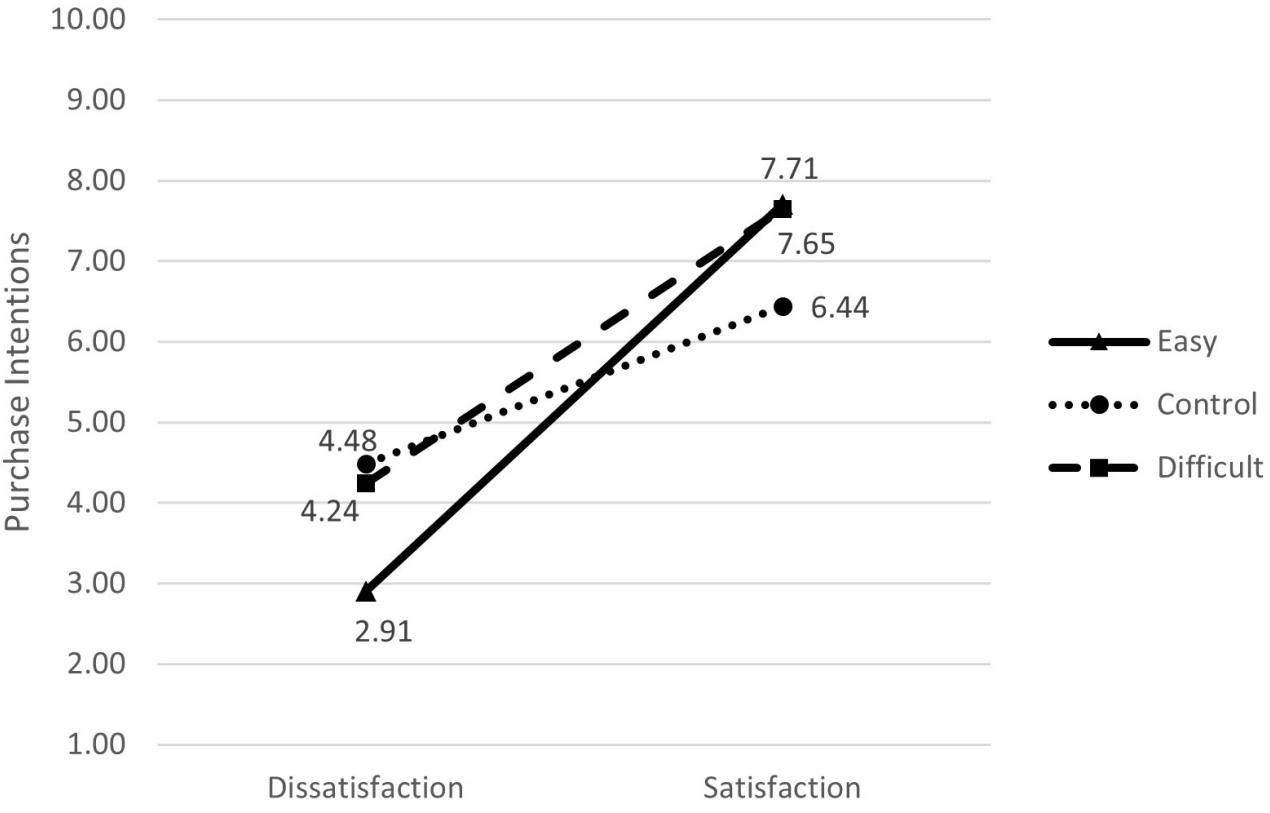

Figure 3. Purchase Intentions: Scenarios vs Fluency

difficulty between the fluency groups ("easy" vs "difficult"). Next, confidence in the evaluations was not measured (Aydin, 2016; Simmons \& Nelson 2006, 2007), so we can only deduce - not state - that individuals reinforce (or abandon) their intuitions/anchors before deciding on their purchase intentions. Last, and yet more important, business relationships can have more events (positive and/ or negative ones) in their lifetimes (Oliver, 2010) and so the scenario manipulation may not fully incorporate this temporal view that results in overall satisfaction (Grönroos, 2009; Oliver, 2010).

\subsection{Experiment 2}

The objectives of experiment 2 were to check for congruence with the results of experiment 1 , to resolve its limitations and to test the mediation effect of confidence. In the second experiment, the respondents' actual business relationships were assessed through an online survey (Appendix B - second experiment questionnaire, disfluency/perceived difficulty). In addition, the questions in the "difficult" manipulation were printed in bold letters to increase the perceived difficulty (DiemandYauman et al., 2011).

Procedures: The experiment had a 3 (fluency: "easy" vs "difficult" vs control) factor design. We opted not to manipulate positive or negative commercial relationships but instead to use satisfaction evaluations of the respondents' present financial service provider. A total of 361 undergraduate students started the test but only 326 completed the survey and were therefore considered valid $\left(43.86 \%\right.$ men, $M_{\text {age }}=29.32$ years, $\left.S D=8.72\right)$.

The individuals were invited by email and social media to participate in a Qualtrics survey about financial services companies. They started by answering sociodemographic questions and then were randomly assigned to one of the three conditions. Similarly to in experiment 1 , in the "easy" task (perceived as easy), the individuals answered four overall satisfaction questions (Prado, 2004) before indicating their purchase intentions. For the "difficult" task (perceived as difficult) they answered four adapted questions made for each concept item (taken from Prado, 2004) - this time printed in bold letters - before indicating their purchase intentions. The control group first indicated their purchase intentions and then evaluated their commercial relationships. The purchase intention question was similar to the one used in experiment 1, but regarding an automobile insurance offer from their present financial services provider. Next, the respondents answered the fluency manipulation check (general perceived difficulty) and reported their confidence in their commercial relationship evaluations, followed by financial services questions regarding their use and buying frequency (these variables reveal non-significant relationships with the results). Following the same procedure 
from experiment 1 , before ending the experiment, all the respondents answered a four-item overall satisfaction scale (Prado, 2004) regarding their present financial services provider (Figure 4 - experiment 2 flow).

Manipulation checks: the one-way anova test revealed that the individuals in the "difficult" group perceived it to be less easy to answer the four satisfaction questions $\left(F(2,323)=26.561, p<0.001, \mathrm{M}_{\text {easy }}=7.47 \mathrm{SD}=2.28\right.$, $\mathrm{M}_{\text {control }}=7.89, \mathrm{SD}=2.35, \mathrm{M}_{\text {difficult }}=5.64, \mathrm{SD}=2.62 /$ $\left.p_{\text {easyXcontrol }}=0.398, p_{\text {easyXdifficult }}<0.001, p_{\text {controlXdifficult }}<0.001\right)$.

Results: to test hypotheses $\mathrm{H} 1$ and $\mathrm{H} 2$, we used the effects on purchase intentions -model 1 (bootstrapping with 5,000 resamples) of the conditional effects module (Hayes, 2013 - SPSS 22). The fluency manipulation results (control: code "-1" vs "easy": code "0" vs "difficult": code "1") revealed significant effects only for the "easy" task compared to the others (coef $=-2.6559, \mathrm{t}=-2.3188$, $p=0.0210, \mathrm{LLCI}=-4.9094, \mathrm{ULCI}=-0.4024 /$ "difficult" vs other groups, $p=0.9490$ ). There was also a significant effect of average satisfaction (questions at the end of the survey) (coef $=0.5013, \mathrm{t}=3.9692, p=0.0001, \mathrm{LLCI}=0.2528$, $\mathrm{ULCI}=0.7499)$ and an interaction effect between factors (fluency and average satisfaction) (coef $=0.4642, \mathrm{t}=2.6112$, $p=0.0095, \mathrm{LLCI}=-0.1144, \mathrm{ULCI}=0.8140)($ Figure 5$)$ and purchase intentions - with the same result pattern as in experiment 1. Easy and difficult questions (vs control group) made satisfied individuals increase their purchase intentions, corroborating hypothesis H2. Additionally, dissatisfied individuals with easy questions (vs difficult and control groups) developed lower purchase intentions, corroborating hypothesis $\mathrm{H} 1$.

Next, we tested whether the confidence in the commercial relationship evaluations could be mediating the effects on the consumers' purchase intentions. First, we classified the individuals into groups according to the satisfaction averages (Cronbach's alpha $=0.790$ ) at the end of the questionnaires. Using Hart and Johnson's (1999) results, the individuals were grouped into: dissatisfied customers (average from 1 to $5.5, \mathrm{n}=89$ ) and satisfied customers ( 6.5 to $10, \mathrm{n}=93$ ) c excluding neutral-satisfied customers from the analyses (5.51 to $6.49, \mathrm{n}=39$ ).

A two-way anova test revealed that valence (satisfied vs dissatisfied groups) had a significant effect on confidence in the evaluations $(\mathrm{CONF})(F(1,268)=70.121$, $p<0.001, \eta_{\mathrm{p}}{ }^{2}=0.078, \mathrm{CONF}_{\text {satisfied }}=7.91, \mathrm{SD}=1.66$, $\left.\mathrm{CONF}_{\text {dissatisfied }}=6.80, \mathrm{SD}=2.03\right)$. Fluency manipulation had a significant effect $(F(2,268)=22.742, p=0.001$, $\eta_{\mathrm{p}}{ }^{2}=0.050, \mathrm{CONF}_{\text {easy }}=7.77, \mathrm{SD}=1.72, \mathrm{CONF}_{\text {control }}$ $\left.=7.71, \mathrm{SD}=1.76, \mathrm{CONF}_{\text {diffficult }}=6.81, \mathrm{SD}=2.08\right)$ and an interaction effect $(F(2,268)=7.176, p=0.001$, $\eta_{\mathrm{p}}{ }^{2}=0.051$ ) without significant differences for satisfied customers, but with significant differences for dissatisfied customers $\left(p_{\text {easyXcontrol }}=0.045, p_{\text {easyXdifficult }}<0.001 p_{\text {controlXdifficult }}\right.$ 0.075) (Figure 6).

Then, with the sample divided between satisfied and dissatisfied customers, the mediating role of evaluation

\begin{tabular}{|c|c|c|}
\hline Fluency & \multirow{6}{*}{$\begin{array}{l}\text { Purchase Intentions } \\
\text { (insurance) } \\
\text { Check: Perceived } \\
\text { Ease in Satisfaction } \\
\text { Evaluations } \\
\text { Confidence in } \\
\text { Commercial } \\
\text { Relationship } \\
\text { Evaluations }\end{array}$} & \multirow{6}{*}{$\begin{array}{l}\text { Socio-demographic } \\
\text { and previous } \\
\text { experience } \\
\text { Check: Commercial } \\
\text { Relationship } \\
\text { Satisfaction }\end{array}$} \\
\hline $\begin{array}{c}\text { Easy Satisfaction } \\
\text { Evaluations }\end{array}$ & & \\
\hline versus & & \\
\hline $\begin{array}{c}\text { Difficult Satisfaction } \\
\text { Evaluations }\end{array}$ & & \\
\hline versus & & \\
\hline $\begin{array}{c}\text { Control: } \\
\text { Without Satisfaction } \\
\text { Evaluations }\end{array}$ & & \\
\hline
\end{tabular}

Figure 4. Experiment 2 Flow. 


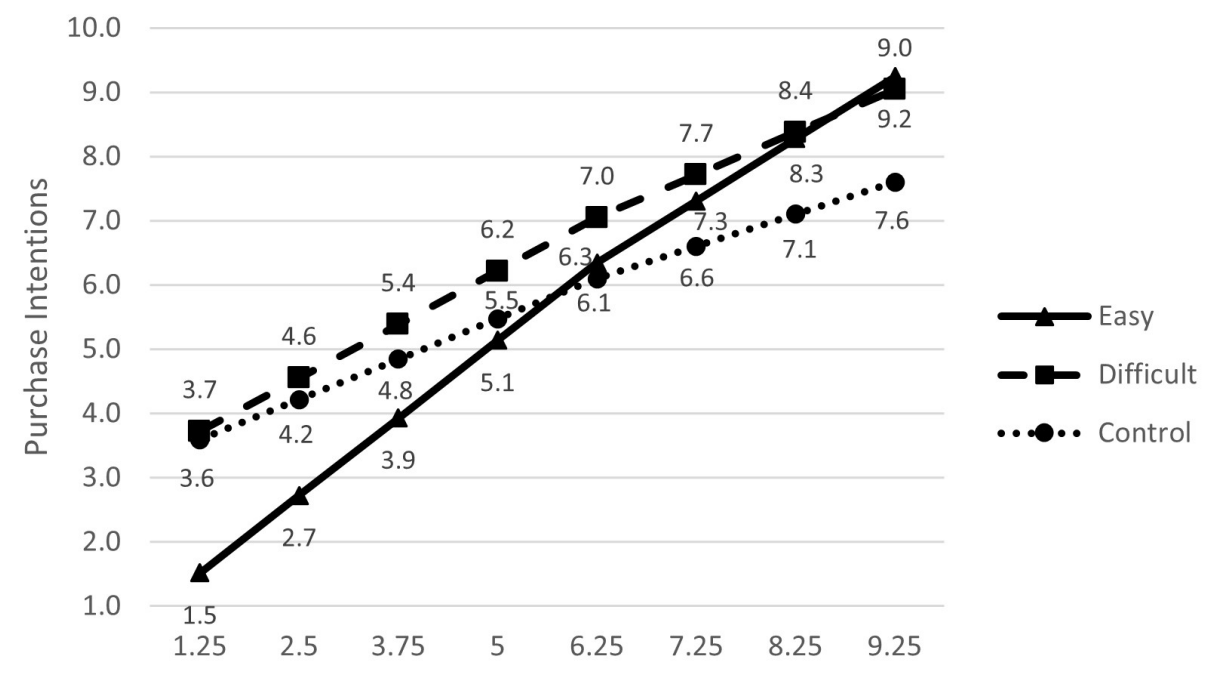

Average Satisfaction (questions at the end of the survey)

Figure 5. Purchase Intentions: Average Satisfaction vs Fluency

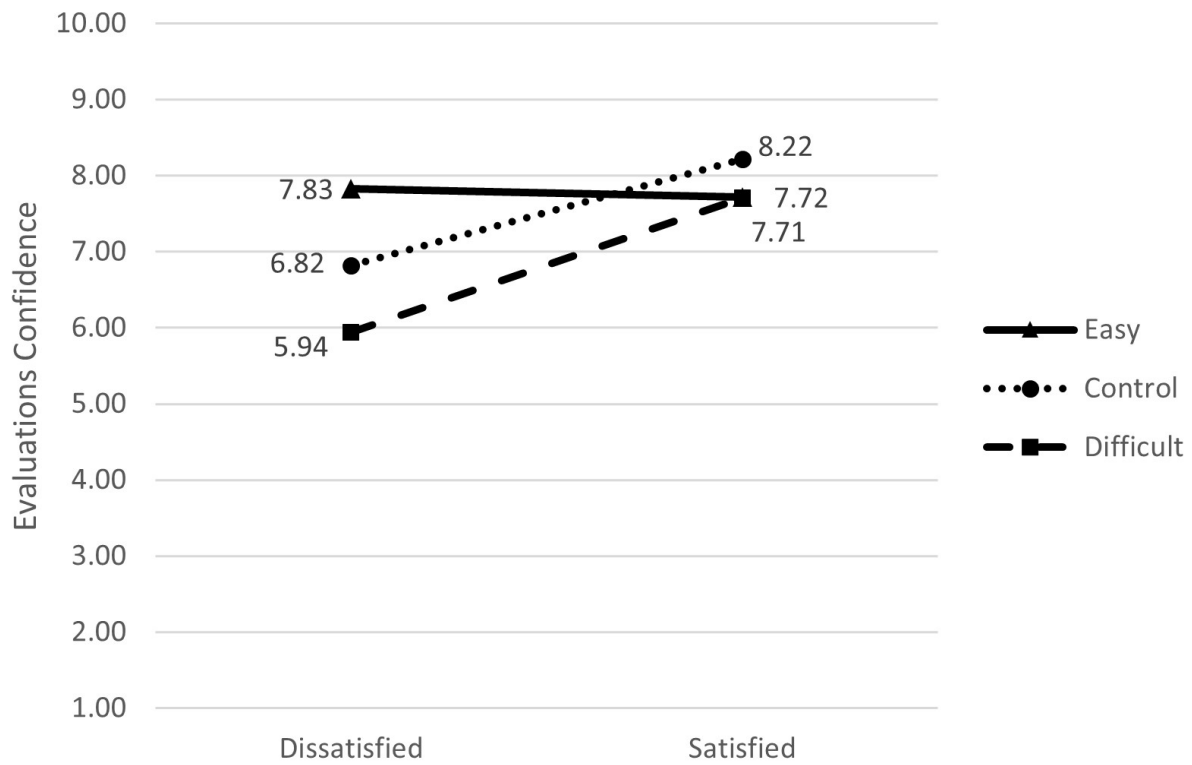

Figure 6. Confidence in Satisfaction Evaluations: Fluency vs Customer Groups

confidence was tested using model 4 (bootstrapping with 5,000 resamples) of the conditional effects module (Hayes, 2013 - SPSS 22) (control: code “-1" vs “easy”: code “0” vs "difficult": code "1").

Satisfied customers with "easy" and "difficult" tasks had higher purchase intentions than the control group $($ coef $=1.0222, \mathrm{t}=3.0037, p=0.0031, \mathrm{LLCI}=0.3496$, $\mathrm{ULCI}=1.6947)$ but there was no significant mediating effect of evaluation confidence (coef $=-0.0056, \mathrm{t}=-0.0559$, $p=0.9555, \mathrm{LLCI}=-0.2028, \mathrm{ULCI}=0.1917)$, therefore corroborating hypothesis $\mathrm{H} 2$ (commercial relationship evaluations - with fluency or disfluency - will directly bias satisfied consumers to increase their subsequent purchase intentions).

In contrast, the mediation analyses for dissatisfied customers revealed that their purchase intentions were only affected by evaluation confidence (coef $=-0.3161$, $\mathrm{t}=-2.7233, p=0.0074, \mathrm{LLCI}=-0.5459, \mathrm{ULCI}=-0.0863$ ). Dissatisfied customers with easy questions before the dependent variable had their confidence increased and then 
indicated lower purchase intentions ("easy" vs "control" vs "difficult": coef $=-0.8316, \mathrm{t}=-1.6617, p=0.0992$, LLCI $=-1.8225$, ULCI $=0.1593)(F(2,120)=7.6423$, $\mathrm{R}^{2}=0.1130 /$ indirect effects Coef $=-0.4816, \operatorname{Se}($ boot $)$ $=0.2020$, LLCI $=-0.9679$, ULCI $=-0.1612$ ), thus corroborating hypothesis $\mathrm{H} 1$.

Discussion: the results from experiment 2, with respondents evaluating their business relationships with financial services companies, converged with the results of experiment 1, with undergraduate students evaluating scenarios (a home telephone, internet, and cable TV company). Both hypotheses were corroborated and it was further demonstrated that dissatisfied customers, despite experiencing a significant decrease in their evaluation confidence in difficult tasks, did not increase their purchase intentions compared to the control group. This is an important result and can only be verified using a control group, which is not pointed out in other studies, as they usually only make the comparison between fluency (perceived ease) and disfluency (perceived difficulty) tasks (Aydin, 2016; Kahneman, 2011; Schwarz, 2004; Simmons \& Nelson, 2006, 2007). Furthermore, although other studies point to higher confidence in tasks perceived as easy, and less confidence in difficult tasks (Aydin, 2016; Epley \& Norwick, 2006, Simmons \& Nelson, 2006, 2007; Kahneman, 2011), this experiment demonstrated that satisfied consumers maintain their overconfidence in their commercial relationship evaluations even in more difficult judgment tasks.

\section{Final Considerations}

\section{I Theoretical implications}

This study demonstrated the implications of the ease and difficulty of satisfaction evaluations on subsequent purchase intentions. It also demonstrated that purchase intention results were influenced by two different mechanisms. Dissatisfied customers with a perception of ease in commercial relationship evaluations developed higher overconfidence, lowering their purchase intentions and thus corroborating the indirect effect hypothesis. Otherwise, satisfied customers with either easy or difficult evaluations showed overconfidence, therefore being directly affected by their evaluations with positive results.

Moreover, the study demonstrated congruent results with other fluency manipulations, but it corroborated the hypotheses by not only comparing difficult versus easy tasks (as in Aydin, 2016; Simons \& Nelson 2006; 2007; among others), but also in comparisons with a control group. Fluency was directly manipulated conceptually by overall satisfaction evaluations, showing the same pattern of results as other studies. However, these other studies' manipulations usually took longer or needed more effort to be concluded - such as in a fact-remembering task (easy: 6 facts vs difficult: 12 facts) (Aarts \& Dijksterhuis, 1999; Haddock, 2002; Viacava et al., 2015). Furthermore, other fluency manipulations, even more subtle ones, can be tested and can lead to similar results. It is possible to verify these effects by manipulating the perceived difficulty with very small letters (Su et al., 2018), using green, yellow, or light blue fonts on a white background (Reber \& Schwarz, 1999), with Brusch or Mistral typefaces (versus Arial) (Song \& Schwarz, 2008), with italics (DiemandYauman et al., 2011), or by inserting more technical or low-knowledge keywords (Oppenheimer, 2004).

Some attention must be paid when trying to use these manipulations, altogether or with the intention of intensifying the effects. When the difficulty is set too high, individuals will stop thinking that "they" have difficulty completing the task, and will start thinking that "the task itself" is too difficult, which can lessen the effects (Schwarz, 2004). In addition, making tasks too difficult and asking individuals to keep doing them could lead to ego depletion effects. Ego depletion is the momentary loss of cognitive capacity (depletion of cognitive resources) due to great effort and/or longer tasks. In ego depletion manipulations individuals are required to suppress their thoughts, inhibit their emotions, act against their principles, avoid reading words in a video, or try to solve great effort anagram tasks (or even unsolvable ones), which can also lead to greater purchase intentions (Baumeister \& Tierney, 2011; Usta \& Häubl, 2011).

\subsection{Managerial implications}

Despite the experiments' results involving a small sample, we were able to verify that the perceived difficulty in satisfaction evaluations led to greater subsequent purchase intentions. If difficult tasks were used in practice (such as here or in other manipulations), satisfied consumers would not have their purchasing decisions negatively affected, while dissatisfied consumers would at least start to deliberate, and thus consider a less intuitive option (Epley \& Norwick, 2006; Simons \& Nelson 2006, 2007). However, here some ethical dilemmas begin. Although 
these tasks could not deplete all the consumers' cognitive resources (Baumeister \& Tierney, 2011) they do affect their ability to make decisions. These tasks do affect consumers' confidence and in doing so they affect their opinions, intuitions, evaluations, and judgments. It is also important to emphasize that although individuals believe they are not being affected by biases (Santos $\&$ Barros, 2011) these effects are present in the daily lives of consumers and decision makers (Kahneman, 2011). Hence, they can make decisions against their intuitions and even against their initial beliefs, with non-beneficial results for them. Nevertheless, we found that the main effect on purchase intentions was due to their commercial relationship evaluations, denoting the need to focus on better quality services that lead to satisfaction (Grönroos, 2009; Oliver, 2010).

\subsection{Limitations and future studies}

Firstly, the main limitation is the use of experiments with small samples and mainly in commercial relationship situations. Thus, further studies using different approaches or assessing different contexts are needed to verify this phenomenon. Here, a new fluency manipulation was demonstrated, but it is still possible to verify some of the fluency effects occurring in our daily lives (Alter \& Oppenheimer, 2009), or to verify the influences of perceived ease or difficulty and overconfidence related to the individuals' ability to process information (such as having difficulties in mathematics) as well as other characteristics. It is possible to verify the impact of factors such as age, the level of education (Mendes-da-Silva \& $\mathrm{Yu}, 2009)$, greater intrinsic experience that affects selfconfidence (Bortoli \& Soares, 2019), and the acceptance of anchors that could influence subsequent decisions (Tronco, Löbler, dos Santos, \& Nishi, 2019). Verifying whether consumers' purchase intentions are affected by their difficulty to calculate monthly interest and installments, or even differences in younger and older people's overconfidence (Mendes-da-Silva \& Yu, 2009), would help store owners to think about how to proceed in such situations.

Moreover, the different techniques to manipulate visual fluency (size or color typefaces, etc.) may produce results without managers' awareness, for example, in eWOM (electronic word of mouth) results. Much has been studied about the motivations for making, receiving, or sharing eWOMs and the impact of perceived credibility
(Chen, Yang, \& Wang, 2016; Hennig-Thurau, Gwinner, Walsh, \& Gremler, 2004). Studies indicate that higher argument quality and writing clarity (general aspects) can positively influence credibility and eWOM acceptance (Cheung, Luo, Sia, \& Chen 2009; Moran, Muzellec, \& Nolan, 2014). Therefore, visual fluency, or even conceptual fluency, may affect the credibility and thus the acceptance of eWOMs.

In addition, future studies could verify whether these effects are related to perceived pleasure or cognitive comfort when processing information (Duke et al., 2014; Labroo \& Pocheptsova, 2016). However, despite the fact that dissatisfied customers may feel greater ease in their commercial evaluations (Claypool et al., 2015; Landwehr et al., 2017), they might not experience pleasure or comfort remembering negative commercial events (Maier \& Dost, 2018).

Finally, individuals may expect difficulties (or ease) in their decisions. If these expectations fit with the difficulty/ease encountered, this congruence would lead to better product evaluations (Jiang \& Hong, 2014). These situations, involving evaluations or decisions, could be more complex and relevant in real-life environments due to low expertise (Payne et al., 1992) - mainly due to low general knowledge about the same or other products.

Thus, it is possible to find different results when consumers are making decisions about the same or other products/services, depending on their involvement.

\section{References}

Aarts, H., \& Dijksterhuis, A. (1999). How often did I do it? Experienced ease of retrieval and frequency estimates of past behavior. Acta Psychologica, 103(1-2), 77-89.

Agnihotri, R., Dingus, R., Hu, M.Y., \& Krush, m. (2016) Social media: Influencing customer satisfaction in B2B sales. Industrial Marketing Management, 53, 172-180.

Albrecht, S., \& Carbon, C-C. (2014) the fluency amplification model: Fluent stimuli show more intense but not evidently more positive evaluations. Acta Psychologica, 148, 195-203.

Alter, A.L., \& Oppenheimer, D.M. (2006) Predicting short-term stock fluctuations by using processing fluency. Proceedings of the National Academy of Sciences, 103(24), 9369-9372. 
Alter, A.L., Oppenheimer, D. M., Epley, N., \& Eyre, R. N. (2007). Overcoming intuition: Metacognitive difficulty activates analytic reasoning. Journal of Experimental Psychology: General, 136(4), 569-576.

Alter, A.L., \& Oppenheimer, D.M. (2009) Uniting the tribes of fluency to form a metacognitive nation. Personality and Social Psychology Review, 13(3), 219-235.

Alter, A.L., \& Oppenheimer, D.M. (2008) Easy on the mind, easy on the wallet: The roles of familiarity and processing fluency in valuation judgments. Psychonomic bulletin \& review, 15(5), 985-990.

Alter, L.A. (2013) The benefits of cognitive disfluency. Current Directions in Psychological Science, 22(6), 437-442.

Aydin, A.E. (2016) Processing fluency: Examining its relationship with thinking style and purchase intention, Journal of Marketing Communications, 24(6), 588-598

Baron, J. (2008). Thinking and deciding: Normative theory of utility and choice (4a ed.). Cambridge: Cambridge University Press.

Bajšanski, I., Žauhar, V., \& Valerjev, P. Confidence judgments in syllogistic reasoning: The role of consistency and response cardinality, Thinking \& Reasoning, 25(1), $14-47$.

Baumeister, R.F., \& Tierney, J. (2011). Willpower: Rediscovering the greatest human strength. New York, NY, US: Penguin Books.

Bettencourt, L. A. (1997). Customer voluntary performance: Customer AX's partners in service delivery. Journal of retailing, 73(3), 383-406.

Bohn A, \& Berntsen D. (2007). Pleasantness bias in flashbulb memories: Positive and negative flashbulb memories of the fall of the Berlin Wall among East and West Germans. Memory and Cognition, 35(3), 565- 577.

Bortoli, C., \& Soares, R. O. (2019). Executivos com maior sofisticação financeira são mais confiantes e otimistas? Revista de administração contemporânea, 23(2), 268-287.

Bowen, H. J., Kark, S. M. \& Kensinger, E. A. (2018). NEVER forget: Negative emotional valence enhances recapitulation. Psychonomic Bulletin \& Review, 25(3), 870-891.

Bless, H., \& Fiedler, K. (2006). Mood and the regulation of information processing and behaviour. In: J. Forgas (ed.) Affect in social thinking and behaviour (pp.65-84). New York: Psychology Press.

Bloemer, J., Ruyter, K., \& Peeters, P (1998). Investigating drivers of bank loyalty: The complex relationship between image, service quality and satisfaction. International Journal of Bank Marketing, 16(7), 276-286.

Bookbinder, S. H., \& Brainerd, C. J. (2017). Emotionally negative pictures enhance gist memory. Emotion, 17(1), 102-119

Brewin, C. R., \& Langley, K. M. R. (2009). Imagery retrieval may explain why recall of negative scenes contains more accurate detail. Memory \& Cognition, 47(3), 420-427.

Caplan, J. B., Sommer, T., Madan, C.R., \& Fujiwara, E. (2019). Reduced associative memory for negative information: Impact of confidence and interactive imagery during study. Cognition and Emotion, 33(8), 1745-1753

Charness, G. E., \& Dave, C. (2017). Confirmation bias with motivated beliefs. Games and Economic Behavior, 104, 1-23.

Chen, Y., Yang, S., \& Wang, Z. (2016). Service cooperation and marketing strategies of Infomediary and online retailer with eWOM effect. Information and Technology Management 17(2), 109-118

Cheung, M. Y., Luo, C., Sia, C. L., \& Chen, H. (2009) Credibility of electronic word-of-mouth: Informational and normative determinants of on-line consumer recommendations, International Journal of Electronic Commerce, 13(4), 9-38.

Claypool, H. M., Mackie, D. M., \& Garcia-Marques, T. (2015). Fluency and attitudes. Social and Personality Psychology Compass, 9(7), 370-382.

Constable, M .D., Bayliss, A. P., Tipper, S. P., \& Kritikos, A. (2013). Self-generated cognitive fluency as an alternative route to preference formation. Consciousness and Cognition, 22(1), 
Diemand-Yauman, C., Oppenheimer, D. M., \& Vaughan, E. B. (2011). Fortune favors the BOLD (and the Italicized): Effects of disfluency on educational outcomes. Cognition, 118(1), 111-5.

Duke, D., Fiacconi, C. M., \& Kohler, S. (2014). Parallel effects of processing fluency and positive affect on familiarity-based recognition decisions for faces. Front. Psychol, 5, 5-328

Epley, N., \& Gilovich, T. (2006). The anchoring-andAdjustment Heuristic. Psychological Science 17(4), 311-318.

Fornell, C., Johnson, M. D., Anderson, E. W., Cha, J., \& Bryant, B. E. (1994). The American customer satisfaction: Nature, purpose and findings. Journal of Marketing, 58(4), 7-18.

Fornell, C., Morgeson , F. V., \& Hult, G. T. (2016). An abnormally abnormal intangible: Stock returns on customer satisfaction. Journal of Marketing, 80(5), 122-125.

Francisco-Maffezzolli, Eliane C., \& Prado, Paulo H. M (2013). Avaliação de resultados no varejo de serviço sob a ótica do consumidor. Revista brasileira de gestão e negocios. 15(46), 112-128.

Garbarino, E., \& Johnson, M.S. (1999). The different roles of satisfaction, trust, and commitment in customer relationships. Journal of Marketing, 63(2), 70-97.

Graf, L.K.M., Mayer, S., \& Landwehr, J. R. (2018). Measuring processing fluency: One versus five items. Journal of Consumer Psychology, 28(3), 393-411.

Grönroos, C. (2009). Marketing: Gerenciamento e serviços. (Marques A. S., \& Belhassof, C. M. Trad.) (3a ed.). Rio de Janeiro: Elsevier.

Haddock, G. (2002). It's easy to like or dislike Tony Blair: Accessibility experiences and the favorability of attitude judgments. British Journal of Social Psychology, 93(2), 257-267.

Hart, C. W., \& Johnson, M. D. (1999). Growing the trust relationship. Marketing Management, 8(1), 9-19.

Hayes, A. F. (2013). Introduction to mediation, moderation, and conditional process analysis. New York: The Guilford Press.
Hennig-Thurau, T., Gwinner, K. P., Walsh, G., \& Gremler, D. D. (2004). Electronic word-of-mouth via consumer-opinion platforms: What motivates consumers to articulate themselves on the Internet? Journal of Interactive Marketing, 18(1), 38-52.

Hernandez, I. \& Preston, J. L. (2013). Disfluency disrupts the confirmation bias. Journal of Experimental Social Psychology, 49(1), 178-182

Herr, P. M. \& Page, C. M. (2004). Asymmetric association of liking and disliking judgments: So what's not to like? Journal of Consumer Research, 30(4), 588-601.

Herr, P. M., Page, C. M., Pfeiffer, B. E., \& Davis, F. D. (2012). Affective influences on evaluative processing. Journal of Consumer Research, 38(5), 833-845.

Hostler, T. J., Wood, C., \& Armitage, C. J. (2018). The influence of emotional cues on prospective memory: A systematic Review with meta-analyses, Cognition and Emotion, 32(8), 1578-1596.

Jiang, Y., \& Hong, J. (2014). It feels fluent, but not right: The interactive effect of expected and experienced processing fluency on evaluative judgment. Journal of Experimental Social Psychology, 54, 147-152

Kahneman, D. (2011). Rápido e Devagar: Duas formas de pensar. Rio de Janeiro: Objetiva.

Kensinger, E. A., \& Schacter, D. L. (2008). Neural processes supporting young and older adults' emotional memories. Journal of Cognitive Neuroscience, 20(7), 1161-73.

Kensinger, E. A. (2009). Remembering the details: Effects of emotion. Emocion Review, 1(2), 99-113.

Kensinger, E. A., \& Mark, S. M. (2018). Emotion and memory. In Stevens' handbook of experimental psychology and cognitive neuroscience. New York: John Wiley \&Sons, inc.

Koch, A. S., \& Forgas, J. P. (2012). Feeling good and feeling truth: The interactive effects of mood and processing fluency on truth judgments. Journal of Experimental Social Psychology, 48(2), 481-485

Kornell, N., Rhodes, M. G., Castel, A. D., \& Tauber, S. K. (2011). The ease-of-processing heuristic and the 
stability bias dissociating memory, memory beliefs, and memory judgments. Psychological Science, 22(6), 787-794

Labroo, A. A., Dhar, R., \& Schwarz, N. (2008). Of frog wines and frowing watches: Semantic priming, perceptual fluency, and brand evaluation. Journal of Consumer Research, 34(6), 819-831.

Labroo, A. A., \& Pocheptsova, A. (2016). Metacognition and consumer judgment: Fluency is pleasant but disfluency ignites interest. Current Opinion in Psychology, 10, 154-159.

Landwehr, J. R., Golla, B., \& Reber, R. (2017). Processing fluency: An inevitable side effect of evaluative conditioning. Journal of Experimental Social Psychology, 70, 124-128.

Larivière, B., Keiningham, T., Aksoy, L., Yalcin, A., Morgeson, F., \& Mithas, S. (2016). Modeling heterogeneity in the satisfaction, loyalty intention, and shareholder value linkage: A cross-industry analysis at the customer and firm levels. Journal of Marketing Research, 53(1), 91-109.

Lazarus, R. S. (1991). Emotion and adaptation. New York: Oxford University Press.

Luppe, M. R., \& Angelo, C. F. de (2010). As decisóes de consumo e a heurística da ancoragem: Uma análise da racionalidade do processo de escolha. RAM Revista de Administração Mackenzie, 11(6), 81-106.

Madan, C. R., Scott, S. M. E., \& Kensinger, E. A. (2019). Positive emotion enhances association-memory. Emotion, 19(4), 733-740.

Maier, E., \& Dost, F. (2018). The positive effect of contextual image backgrounds on fluency and liking. Journal of Retailing and Consumer Services, 40, 109-116.

Malhotra, N. K. (2010). Pesquisa de marketing: Uma orientaçâo aplicada. Porto Alegre: Bookman.

Matovic, D., Kock, A. S., \& Forgas, J. P. (2014). Can negative mood improve language understanding? Affective influences on the ability to detect ambiguous communication. Journal of Experimental Social Psychology, 52, 44-49.

Mendes-Da-Silva, W., \& Yu, A. S. O. (2009). Análise empírica do senso de controle: Buscando entender o excesso de confiança. Revista de administração contemporânea, 13(2), 247-271.

Miele, D. B., \& Molden, D. C. (2010). Naive theories of intelligence and the role of processing fluency in perceived comprehension. Journal of Experimental Psychology: General, 139(3), 535-557.

Moran, G., Muzellec, L., \& Nolan, E. (2014) Consumer moments of truth in the digital context: How "search" and "e-word of mouth" can fuel consumer decision-making. Journal of Advertising Research, 54(2), 200-204

Nunes, J. C., Ordani, A., \& Valsesia, F. (2015). The power of repetition: Repetitive lyrics in a song increase processing fluency and drive market success. Journal of Consumer Psychology, 25(2), 187-199.

Oliver, R. L. (2010). Satisfaction, a behavioural perspective on the consumer (2. ed.). New York: Irwin McGraw-Hill.

Oppenheimer, D. M. (2004) Spontaneous discounting of availability in frequency judgment tasks. Psychological Science, 15(2), 100-105

Oppenheimer, D. M., \& Alter, A. L. (2013). Disfluency sleeper effect: Disfluency today promotes fluency tomorrow. In C. Unkelbach \& Rom. Greifender (Eds.), The experience of thinking: How the fluency of mental processes influences cognition and behaviour (pp. 85-97). New York: Psychology Press.

Orita, R. \& Hattori, M. (2018). Positive and negative affects facilitate insight problem-solving in different ways: A study with Implicit hints. Japanese Psychological Research, Special issue: Implicit Cognition, 61(2), 94-106

Patrick, V. M., Chun, H. H., \& Macinnis, D. J. (2009) Affective forecasting and self-control: Why anticipating pride wins over anticipating shame in a self-regulation context. Journal of Consumer Psychology, 19(3), 537-545.

Payne, J. W., Bettman, J. R., Coupey, E., \& Johnson, E. J. (1992). A constructive process view of decision making: Multiple strategies in judgment and choice. Acta Psychologica, 80(1-3), 107-141.

Park, Y., Herr, P. M., \& Kim, B. C. (2016). The effect of disfluency on consumer perceptions of information security. Marketing Letters, 27(3), 525-535. 
Prado, P. H. M. (2004). A avaliação do relacionamento sob a ótica do cliente: Um estudo em bancos de varejo. Tese (Doutorado em Administraçáo) - Programa de Pós-Graduação em Administração de Empresas. Escola de Administração de Empresas de São Paulo, Fundação Getúlio Vargas, São Paulo.

Prato, F., \& John, O. P. (1991). Automatic vigilance: The attention-grabbing power of negative Social Information. Journal of Personality and Social Psychology, 61(3), 380-391.

Reber, R., \& Schwarz, N. (1999). Effects of perceptual fluency on judgments of truth. Consciousness and Cognition, 8(3), 338-342

Rowe G, Hirsh, J. B., \& Anderson A.K. (2007). Positive affect increases the breadth of attentional selection. Proceedings of the National Academy of Sciences, 104(1), 383-388.

Ryffel, F. A., \& Wirth, W. (2016). Heart versus mind: How affective and cognitive message frames change attitudes. Social Psychology, 47(1), 52-62.

Ryffel, F. A., \& Wirth, W. (2018). How perceived processing fluency influences the illusion of knowing in learning from TV reports. Journal of Media Psychology, 32(1), 2-13

Sanchez, C., \& Jaeger, A. J. (2015). If it's hard to read, it changes how long you do it: Reading time as an explanation for perceptual fluency effects on judgment. Psychon B ull Rev, 22(1), 206-211.

Santos, J. O. dos, \& Barros, C. A.S. (2011). O que determina a tomada de decisáo financeira: Razão ou emoção?. Revista brasileira gestão de negócios, 13(38), 7-20.

Schwarz, N. (2004). Metacognitive experiences in consumer judgment and decision making. Journal of Consumer Psychology, 14(4), 332-348.

Shadish, W. R., Cook, T. D., \& Campbell, D. T. (2002). Experimental and quasi-experimental designs for generalized causal inference. In Cook, T. D. \& Campbell (Ed.) Journal of the American Statistical Association, 100. Boston: Houghton Mifflin

Silva, R. R., Garcia-Marques, T., \& Reber, R. (2017). The informative value of type of repetition: Perceptual and conceptual fluency influences on judgments of truth.
Consciousness and Cognition: An International Journal, 51, 53-67.

Simmons, J.P., Nelson, L.D. (2006). Intuitive confidence: Choosing between intuitive and nonintuitive alternatives. Journal of Experimental Psychology, 35(3), 409-428.

Simmons, J. P., \& Nelson, L. D. (2007). Intuitive confidence: When consumer choices are sensitive to matching prices. Association for Consumer Research, 34, 265-268

Sirgy, J. M. A. (1984) Social cognition model of consumer satisfaction/dissatisfaction: An experiment. Psychology \& Marketing, 1(2), 27- 44.

Song, H., \& Schwarz, N. (2008). If it's hard to read, it's hard to do: Processing fluency affects effort prediction and motivation. Psychological Science, 19(10), 986-988.

Storbeck J., \& Clore G.L. (2005). With sadness comes accuracy; with happiness, false memory: Mood and the false memory effect. Psychological Science, 16(1), 785-791.

Su, N., Li, T., Zheng, J., Hu, X., Fan, T., \& Lu L. (2018). How font size affects judgments of learning: Simultaneous mediating effect of item-specific beliefs about fluency and moderating effect of beliefs about font size and memory. PLOS ONE 13, 1-14.

Talarico, J. M., Berntsen, D., \& Rubin, D. C. (2009). Positive emotions enhance recall of peripheral details. Cognition and Emotion, 23(2), 380-398.

Tronco, P. B., Lobler, M. L., Santos, L. G., \& Nishi, J. M. (2019). Heurística da ancoragem na decisão de especialistas: Resultados sob teste de manipulação. Revista de Administração Contemporânea, 23(3), 331-350.

Usta, M., \& Häubl, G. (2011). Self-regulatory strength and consumers' relinquishment of decision control: When less effortful decisions are more resource depleting. Journal of Marketing Research, 48(2), 403-412.

Viacava, J. J. C, Mantovani, D., Korelo, J. C., \& Prado, P. H. M. (2015). Vieses na satisfação: O efeito moderador da dificuldade e da obrigação sobre recordações positivas e negativas. REAd. Revista eletrônica administraçāo. 21(2), 437-461. 
Winkielman, P., \& Schwarz, N. (2001). How pleasant was your childhood? Beliefs about memory shape inferences from experienced difficulty of recall. Psychological Science, 12(2), 176-179.

Yang, C., Huang, T. E., \& Shanks, D. R. (2018). Perceptual fluency affects judgments of learning: The font size effect. Journal of Memory and Language, 99(1), 99-110

Weissgerber, C. S., \& Reinhard, M. A. (2017). Is disfluency desirable for learning? Learning and Instruction, 49, 199-217. 


\section{Appendix A - First experiment questionnaires}

[Scenario: Positive - Satisfaction; Type: control, Easy Commercial Relationship Evaluations after Purchase Intentions]

Eduardo has been a client of the ALPHA Company, Internet and home telephone service provider for 3 years. ALPHA's employees always seem to understand his needs. Eduardo is not a specialist on the Internet and home telephone services, so sometimes, he cannot explain precisely what he needs. But, he always sure that ALPHA's employees will try to understand him and, do will always seek the best solution for him.

Employees from ALPHA Company always met their deadlines. When Eduardo had a problem, an employee promised him a solution in up to 2 days. Two days later, the problem was solved. If you need anything from that company, it will not be time consuming, and it will be quickly resolved - no time will be wasted in the telephone service queue or to have any request answered over the internet.

Also, it is important to point out that all services from the company ALPHA are well performed. Internet and home telephones never seem to have any problems. Whenever the company performs some "maintenance on the network", he always gets at least a 03 day warning in advance.

Eduardo says: "Everyone says that Internet and home-phones providers are all the same, but this company seems to be the best of all. I have been a client of other companies, but I have never had so few problems and, they never made me waste time! It is not a joke!"

[...unrelated surveys...]

[Dependent Variable - Purchase Intentions]

Eduardo was thinking about hiring a cable TV plan, and last week he received a call from the company ALPHA to change his subscription to include TV cable services for BRL 125,00 more in his bill, same price offer that a friend of his got for the same service.

By putting yourself in Eduardo's shoes and based only on the commercial relationship previously described, would you hire the cable TV service from ALPHA Company?

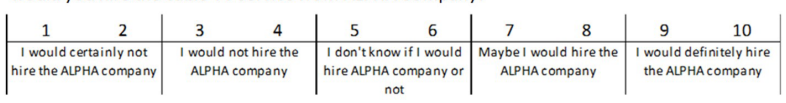

[Manipulation Check: perceived ease/difficulty in evaluating the commercial relationship] How difficult was it for you to answer the questions regarding your satisfaction with ALPHA Company - the provider of home-phones, Internet and Cable TV services - in Eduardo's story?

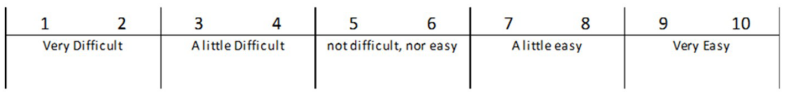

[questions about the their current home-phone, internet and cable TV company]

[socio-demographic questions: age /gender/marital status / income]

[Scenario Check: Satisfaction Evaluations]

By putting yourself in Eduardo's place (the client of the story), answer:

How would you rate your satisfaction with this company - ALPHA, the provider of home-phones, Internet, and Cable TV services?

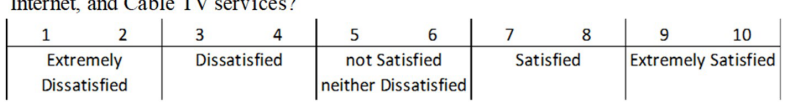

Evaluate whether you agree with the statement:

"I would very much like to continue purchasing and having a commercial relationship with this ALPHA company - the provider of home-phones, Internet, and Cable TV services."

\begin{tabular}{|c|c|c|c|c|}
\hline 1 & 3 & 6 & 7 & 10 \\
\hline I Strongly Disagree & I Disagree & $\begin{array}{c}\text { neither Agree nor } \\
\text { Disagree }\end{array}$ & I Agree & I Strongly Agree \\
\hline
\end{tabular}

How would you rate the commercial relationship with this ALPHA company - the provider of homephones, Internet, and Cable TV services - according to your expectations?

\begin{tabular}{|c|c|c|c|c|}
\hline 1 & 4 & 5 & 8 & 10 \\
\hline $\begin{array}{l}\text { Way below my } \\
\text { expectations }\end{array}$ & $\begin{array}{c}\text { Below my } \\
\text { expectations }\end{array}$ & as expected & $\begin{array}{c}\text { Above my } \\
\text { expectations }\end{array}$ & $\begin{array}{c}\text { Way above my } \\
\text { expectations }\end{array}$ \\
\hline
\end{tabular}

How would you rate the commercial relationship with this ALPHA company - the provider of homephones, Internet, and Cable TV services?

\begin{tabular}{|c|c|c|c|c|}
\hline 1 & 4 & 5 & 8 & 10 \\
\hline Too far from ideal & Far from ideal & $\begin{array}{c}\text { neither far nor } \\
\text { near ideal }\end{array}$ & Close to ideal & $\begin{array}{l}\text { Very close close to } \\
\text { the ideal }\end{array}$ \\
\hline
\end{tabular}

[Closure]

Thank you very much for participating in the research. If you have any questions or suggestions, please write in the space below. 
[Scenario: Negative - Dissatisfaction; Type: Easy Commercial Relationship Evaluations before Purchase Intentions]

Eduardo has been a client of ALPHA Company, Internet and home telephone service providers for 3 years. ALPHA's employees never seem to understand his needs. Eduardo is not a specialist on the Internet and home telephone services, so sometimes, he cannot explain precisely what he needs. But, he always has the impression that ALPHA's employees do not try to understand him and do not seek the best solution for him.

Employees from ALPHA Company never met their deadlines. When Eduardo had a problem, an employee promised him a solution in up to 2 days. Two days later, nothing happened, the problem was not solved (not even a week later ...). If you need anything from that company, it will be time consuming - a lot of time is wasted in the telephone service queue or to have any request answered over the internet.

Also, it is important to point out that all services from the company ALPHA are not well performed. Internet and home telephones have frequent problems. Whenever Eduardo has to use their services urgently, some "maintenance on the network" seems to be being done without warnings in advance.

Eduardo says: "Everyone says that Internet and home-phones providers are all the same, but this company seems to be the worst of all. I have been a client of other companies, but I have never had so many problems or, have never wasted so much time before! It is not a joke!"

\section{[...unrelated surveys...]}

[Easy Commercial Relationship Evaluations before Purchase Intentions]

Putting yourself in Eduardo's place (the client of the story), answer:

How would you rate your satisfaction with this company - ALPHA, the provider of home-phones, Internet, and Cable TV services?

\begin{tabular}{|c|c|c|c|c|}
\hline 1 & 3 & 6 & 7 & 10 \\
\hline $\begin{array}{l}\text { Extremely } \\
\text { Dissatisfied }\end{array}$ & Dissatisfied & \begin{tabular}{|c|} 
not Satisfied \\
neither Dissatisfied
\end{tabular} & Satisfied & Extremely Satisfied \\
\hline
\end{tabular}

Evaluate whether you agree with the statement:

"I would very much like to continue purchasing and having a commercial relationship with this ALPHA company - the provider of home-phones, Internet, and Cable TV services."

\begin{tabular}{|c|c|c|c|c|}
\hline 2 & 3 & 5 & 7 & 10 \\
\hline I Strongly Disagree & I Disagree & $\begin{array}{l}\text { neither Agree nor } \\
\text { Disagree }\end{array}$ & I Agree & ongly Agree \\
\hline
\end{tabular}

How would you rate the commercial relationship with this ALPHA company - the provider of homephones, Internet, and Cable TV services - according to your expectations?

\begin{tabular}{|c|c|c|c|c|}
\hline 2 & 3 & 5 & 8 & 10 \\
\hline $\begin{array}{c}\text { Way below my } \\
\text { expectations }\end{array}$ & $\begin{array}{c}\text { Below my } \\
\text { expectations }\end{array}$ & as expected & $\begin{array}{c}\text { Above my } \\
\text { expectations }\end{array}$ & $\begin{array}{l}\text { Way above my } \\
\text { expectations }\end{array}$ \\
\hline
\end{tabular}

How would you rate the commercial relationship with this ALPHA company - the provider of homephones, Internet and Cable TV services?

\begin{tabular}{|c|c|c|c|c|}
\hline 2 & 4 & 6 & 8 & 10 \\
\hline Too far from ideal & Far from ideal & $\begin{array}{c}\text { neither far nor } \\
\text { near ideal }\end{array}$ & Close to ideal & $\begin{array}{l}\text { Very close close to } \\
\text { the ideal }\end{array}$ \\
\hline
\end{tabular}

[Dependent Variable - Purchase Intentions]

Eduardo was thinking about hiring a cable TV plan, and last week he received a call from company ALPHA to change his subscription to include TV cable services for BRL 125,00 more in his bill, same price offer that a friend of his got for the same service.

By putting yourself in Eduardo's shoes and based only on the commercial relationship previously described, would you hire the cable TV service from ALPHA Company?

\begin{tabular}{|c|c|c|c|c|}
\hline 1 & 3 & 5 & 7 & 10 \\
\hline $\begin{array}{l}\text { I would certainly not } \\
\text { hire the ALPHA company }\end{array}$ & $\begin{array}{l}\text { I would not hire the } \\
\text { ALPHA company }\end{array}$ & $\begin{array}{l}\text { I don't know if I would } \\
\text { hire ALPHA company or } \\
\text { not }\end{array}$ & $\begin{array}{l}\text { Maybel would hire the } \\
\text { ALPHA company }\end{array}$ & $\begin{array}{l}\text { I would definitely hire } \\
\text { the ALPHA company }\end{array}$ \\
\hline
\end{tabular}

[Manipulation Check: perceived ease/difficulty in evaluating the commercial relationship]

How difficult was it for you to answer the questions regarding your satisfaction with ALPHA Company - the provider of home-phones, Internet and Cable TV services - in Eduardo's story?

\begin{tabular}{|c|c|c|c|c|}
\hline 2 & 4 & 6 & $\begin{array}{ll}7 & 8 \\
\end{array}$ & $9 \quad 10$ \\
\hline Very Difficult & Alittle Difficult & not difficult, nor easy & A little easy & Very Easy \\
\hline
\end{tabular}

[questions about the their current home-phone, internet and cable TV company]

[socio-demographic questions: age / gender / marital status / income]

[Scenario Check: Satisfaction Evaluations]

[Closure]

Thank you very much for participating in the research. If you have any questions or suggestions, please write in the space below. 
[Scenario: Positive - Satisfaction; Type: Difficult Commercial Relationship Evaluations before Purchase Intentions]

Eduardo has been a client of ALPHA Company, Internet and home telephone service providers for 3 years. ALPHA's employees always seem to understand his needs. Eduardo is not a specialist on the Internet and home telephone services, so sometimes, he cannot to explain precisely what he needs. But, he is always sure that ALPHA's employees will try to understand him and, do will always seek the best solution for him.

Employees from ALPHA Company always met their deadlines. When Eduardo had a problem, an employee promised him a solution in up to 2 days. Two days later, the problem was solved. If you need anything from that company, it will not be time consuming, and it will be quickly resolved - no time will be wasted in the telephone service queue or to have any request answered over the internet.

Also, it is important to point out that all services from the company ALPHA are well performed. Internet and home telephones never seem to have any problems. Whenever the company performs some "maintenance on the network", he always gets at least a 03 day warning in advance.

Eduardo says: "Everyone says that Internet and home-phones providers are all the same, but this company seems to be the best of all. I have been a client of other companies, but I have never had so few problems and, they never made me waste time! It is not a joke!!"

[...unrelated surveys...]

[Difficult evaluations before Purchase Intentions]

Putting yourself in Eduardo's place (the client of the story), answer:

In a broadly, in an overall or expanded way, how would you rate the commercial relationship with this company (ALPHA), the provider of home-phones, Internet and Cable TV services, focusing on the services offered, regarding the satisfaction's acts or effects?

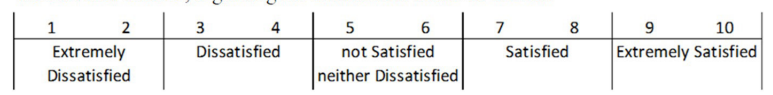

Evaluate whether you agree with the statement:

"I would very much like to take on a commercial process forward, not discontinuing and / or not extinguishing, the relationship with this company (ALPHA), the provider of home-phones, Internet and Cable TV services, mentioned in the story."

\begin{tabular}{|c|c|c|c|c|}
\hline 1 & 3 & 6 & 7 & 10 \\
\hline I Strongly Disagree & I Disagree & $\begin{array}{l}\text { neither Agree nor } \\
\text { Disagree }\end{array}$ & I Agree & I Strongly Agre \\
\hline
\end{tabular}

How would you rate the commercial relationship with this ALPHA company), provider of homephones, Internet and Cable TV services, mentioned in the story, according to your anticipations, predictions of future consequences that form references that will fulfill needs, considering internal information as the main basis, even if would be influenced by external references?

\begin{tabular}{|c|c|c|c|c|}
\hline 1 & 4 & 5 & 8 & 10 \\
\hline $\begin{array}{l}\text { Way below my } \\
\text { expectations }\end{array}$ & $\begin{array}{l}\text { Below my } \\
\text { expectations }\end{array}$ & as expected & $\begin{array}{l}\text { Above my } \\
\text { expectations }\end{array}$ & $\begin{array}{l}\text { Way above } \mathrm{m} \\
\text { expectations }\end{array}$ \\
\hline
\end{tabular}

How would you rate your relationship with this ALPHA company, the provider of home-phones, Internet and Cable TV services, mentioned in the story, regarding your ideals and perceptions - since they are objects of aspirations and desires, social and / or individual formed for this category of

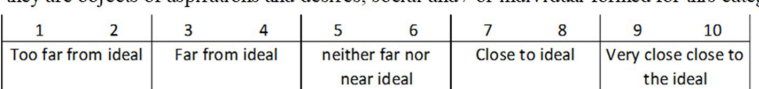

[Dependent Variable - Purchase Intentions]

Eduardo was thinking about hiring a cable TV plan, and last week he received a call from the company ALPHA to change his subscription to include TV cable services for BRL 125,00 more in his bill, same price offer that a friend of his got for the same service.

By putting yourself in Eduardo's shoes and based only on the commercial relationship previously described,

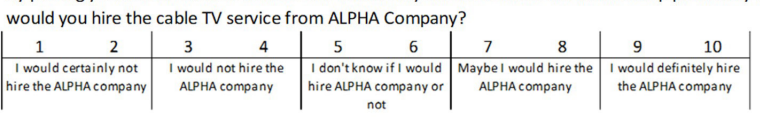

[Manipulation Check: perceived ease/difficulty in evaluating the commercial relationship] How difficult was it for you to answer the questions regarding your satisfaction with ALPHA Company - the provider of home-phones, Internet and Cable TV services - in Eduardo's story?

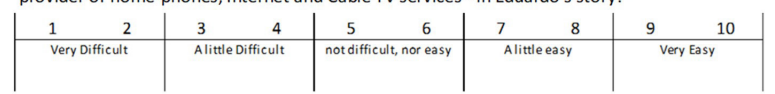

[questions about the their current home-phone, internet and cable TV company]

[socio-demographic questions: age /gender/marital status / income]

[Scenario Check: Satisfaction Evaluations]

[Closure]

Thank you very much for participating in the research. If you have any questions or suggestions, please write in the space below. 


\section{Appendix B - Second experiment questionnaire, disfluency/perceived difficulty}

[Type: Difficult Commercial Relationship Evaluations before Purchase Intentions]

Dear, we count on your participation in a research on BANKING SERVICES. Some questions about service provision will be presented.

The survey takes approximately 5 minutes, and there are no right or wrong answers (just answer as best you can).

[Socio-demographic questions: age / gender / marital status / income]

Are you now a customer of any bank (financial services company)?

( ) Yes

( ) No [ends the research]

[Difficult evaluations before Purchase Intentions]

In a broad manner, overall and expanded way, how would you rate the commercial relationship with your current banking / financial se rvices company, focusing on the services offered, regarding the satisfaction's acts or effects?

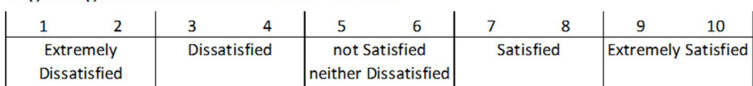

Evaluate whether you agree with the statement:

"I would very much like to take on a commercial process forward, not discontinuing and / or not extinguishing, the relationship with your current banking / financial services company."

\begin{tabular}{|c|c|c|c|c|}
\hline 1 & 3 & 5 & 7 & 10 \\
\hline I Strongly Disagree & I Disagree & $\begin{array}{c}\text { neither Agree nor } \\
\text { Disagree }\end{array}$ & I Agree & I Strongly Agree \\
\hline
\end{tabular}

How would you rate the commercial relationship with your current banking / financial service company, according to your anticipations, predictions of future consequences that form references that will fulfill needs, considering internal information as the main basis, even if external references would influence it?

\begin{tabular}{|c|c|c|c|c|}
\hline 2 & 4 & 5 & 8 & 10 \\
\hline $\begin{array}{l}\text { Way below my } \\
\text { expectations }\end{array}$ & $\begin{array}{c}\text { Below my } \\
\text { expectations }\end{array}$ & as expected & $\begin{array}{c}\text { Above my } \\
\text { expectations }\end{array}$ & $\begin{array}{l}\text { Way above my } \\
\text { expectations }\end{array}$ \\
\hline
\end{tabular}

How would you rate your relationship with your current banking / financial services company, regarding your ideals and pe rceptions - since they are objects of aspirations and desires, social and / or individual formed for this category of services?

\begin{tabular}{|c|c|c|c|c|}
\hline 1 & 4 & 6 & 8 & 10 \\
\hline Too far from ideal & Far from ideal & $\begin{array}{c}\text { neither far nor } \\
\text { near ideal }\end{array}$ & Close to ideal & $\begin{array}{c}\text { Very close clos } \\
\text { the ideal }\end{array}$ \\
\hline
\end{tabular}

[Dependent Variable: Purchase Intentions]

Now imagine yourself in this present situation.

You went to your bank to ask for an insurance proposal for a car you have just bought. The bank price offer to issue an insurance for your car was BRL1,500.00 - pretty similar price to what a friend of yours received for his car (same year and same model).

Would you insure your car, accepting this offer from your current bank? (Your current financial services company)

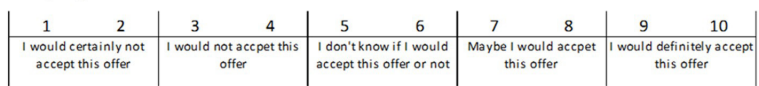

[Manipulation Check: perceived ease/difficulty in evaluating the commercial relationship]

How difficult was it for you to answer the questions regarding your satisfaction with your current bank?

(The first survey questions that were about services, ideals and expectations --- before the question about car insurance)

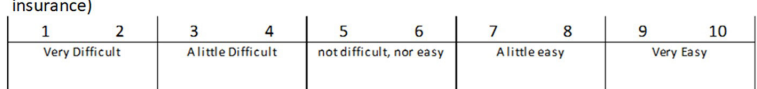

[Confidence in evaluating the commercial relationship]

"How much confidence did you have when you were evaluating you current bank satisfaction? (The first survey questions about services, ideals and expectations --- before the question about car insurance)

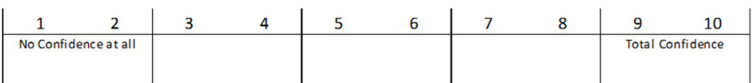

[questions about the their current banking company, if they had any cars, car insurances, actual insurance fees] [Commercial Relationship Check: Satisfaction Evaluations]

[Closure]

Thank you very much for participating in the research. If you have any questions or suggestions, please write in the space below. 


\section{Authors:}

1. Juan José Camou Viacava, PhD, Federal University of Paraná, Curitiba, Brazil.

E-mail: juanjcviacava@gmail.com

ORCID

(D) 0000-0002-1945-0592

2. Paulo de Paula Baptista, PhD, University of Sao Paulo, USP - FEA, Sao Paulo, Brazil.

E-mail: paulopbapista@gmail.com

ORCID

(D) $0000-0003-4885-5086$

\section{Contribution of each author}

\begin{tabular}{lcc}
\hline \multicolumn{1}{c}{ Contribution } & Juan José Camou Viacava & Paulo de Paula Baptista \\
\hline 1. Definition of research problem & $\sqrt{ }$ & $\sqrt{ }$ \\
2. Development of hypotheses or research questions (empirical studies) & $\sqrt{ }$ \\
3. Development of theoretical propositions (theoretical work) & & $\sqrt{ }$ \\
4. Theoretical foundation/literature review & $\sqrt{ }$ \\
5. Definition of methodological procedures & $\sqrt{ }$ \\
6. Data collection & $\sqrt{ }$ \\
7. Statistical analysis & $\sqrt{ }$ \\
8. Analysis and interpretation of data & $\sqrt{ }$ \\
9. Critical revision of the manuscript & $\sqrt{ }$ \\
10. Manuscript writing & & $\sqrt{ }$ \\
11. Other & & $\sqrt{ }$ \\
\hline
\end{tabular}

